\title{
PROFIL TOKSIKOLOGIS EKSTRAK DAUN TUMBUHAN BAKA-BAKA (Hyptis capitata Jacq.) PADA HATI TIKUS PUTIH
}

\section{TOXICOLOGICAL PROFILE OF PLANT BAKA-BAKA (Hyptis capitata Jacq.) LEAF EXTRACT IN RATS LIVER}

\author{
Sitti Ayu Suhartina Yahya, Wahyu Harso, dan Magfirahtul Jannah* \\ Jurusan Biologi Fakultas Matematika dan IImu Pengetahuan Alam Universitas Tadulako Tondo \\ Palu, Sulawesi Tengah 94118
}

Keywords:

Toxicology, Hyptis capitata

Jacq., Hystopathology,

Liver

Kata Kunci:

Toksikologi, Hyptis

capitata Jacq.,

Histopatologi, Hati

\begin{abstract}
Hyptis capitata Jacq. plant has been using for traditional medicine. Utilization of medicinal plant must always consider to given dose because of toxic effect when too much medicine is taken. The aim of this study was to measure the liver damage in rats caused by $\mathrm{H}$. capitata Jacq. leave extract. Either 300 (P1), 600 (P2) or 900 (P3) $\mu \mathrm{g} / \mathrm{kgBW} H$. capitata Jacq. leave extract was given orally to rats every 24 hours during 14 days. Zero point five $\mathrm{ml}$ ethanol $96 \%$ was given daily (K-) and without given anything $(\mathrm{K}+)$ was also conducted as a control. Both macroscopic and microscopic of liver damage were assessed. The result showed that rats given P3 treatment had the highest liver damage. The liver damage in rats was not statistically significant difference between P3 and K- treatments. The lowest liver damage was in rats given $\mathrm{K}+$ treatment. There was no significant difference between $\mathrm{P} 1$ and $\mathrm{P} 2$ treatments on rats liver damage. Utilization of medicinal plant as traditional medicine should always be consider to doses.
\end{abstract}

\begin{abstract}
ABSTRAK
Tumbuhan Hyptis capitata Jacq. telah lama digunakan sebagai obat tradisional. Pemanfaatan tumbuhan obat harus tetap memperhatikan dosis karena bila melebihi akan menimbulkan efek toksik. Tujuan dari penelitian ini adalah untuk mengetahui kerusakan hati pada tikus karena diberi ekstrak daun $\mathrm{H}$. capitata. Penelitian dilakukan dengan memberikan 300 (P1), 600 (P2) atau 900 (P3) $\mu \mathrm{g} / \mathrm{kgBB}$ ekstrak daun H. capitata Jacq. setiap hari secara oral kepada tikus selama 14 hari dengan durasi pemberian 24 jam. Pemberian $0,5 \mathrm{ml}$ etanol $96 \%$ perhari (K-) dan tanpa pemberian perlakuan $(\mathrm{K}+)$ juga dilakukan sebagai pembanding. Parameter penilaian adalah kerusakan hati secara makroskopik dan mikroskopik. Hasil penelitian menunjukkan bahwa kerusakan sel hati tertinggi diperoleh pada tikus yang diberi perlakuan P3 yang nilainya tidak berbeda nyata dengan kerusakan hati tikus yang diberi perlakuan K-. Kerusakan sel hati terendah terdapat pada tikus yang diberi perlakuan $\mathrm{K}+$. Tidak ada perbedaan yang nyata antara kerusakan hati tikus yang disebabkan perlakuan P1 dan P2. Penggunaan tumbuhan obat sebagai obat tradisional sebaiknya tetap memperhatikan dosisnya.
\end{abstract}

Corresponding Author : magfirahtul@untad.ac.id 


\section{PENDAHULUAN}

Hyptis capitata Jacq. atau yang dikenal di daerah Palolo, Sulawesi Tengah dengan nama baka-baka merupakan tumbuhan herba daerah tropis dari famili Lamiaceae yang telah dimanfaatkan secara luas sebagai tumbuhan obat, misalnya oleh masyarakat Taiwan (Almtorp et al., 1991), Cina (Xu et al., 2013), dan Suku Topo Uma di Sulawesi Tengah, Indonesia (Alvionita, 2017). Walaupun demikian, H. capitata Jacq. tidak dapat disarankan penggunaannya kepada masyarakat tanpa informasi yang memadai terkait dosis dan efeknya bagi organ tubuh, sebab semua jenis obat yang dikonsumsi dapat menimbulkan efek toksik jika mencapai dosis tertentu (Manggung, 2008).

Tingkat keamanan suatu bahan obat dapat diketahui dengan melakukan uji

\section{BAHAN DAN METODE}

Penelitian dilakukan pada bulan Juni hingga September 2018. Pengambilan sampel dilakukan di Kecamatan Palolo, Kabupaten Sigi, Provinsi Sulawesi Tengah. Pembuatan ekstrak, perlakuan hewan uji, pembuatan preparat histopatologi dan pengamatan struktur makroskopik dan mikroskopik hati tikus putih ( $R$. norvegicus) dilakukan di Laboratorium Biomedik, Laboratorium Bioteknologi Jurusan Biologi Fakultas Matematika dan IImu Pengetahuan Alam Universitas Tadulako dan Laboratorium Biologi Fakultas Keguruan dan IImu Pendidikan Universitas Tadulako.

\section{Bahan}

ISSN-P : 1978-6417; ISSN-E : 2580-5991 toksisitas menggunakan hewan uji sebagai model, untuk melihat reaksi biokimia, fisiologi dan patologi manusia terhadap bahan yang diteliti (Soemardji dkk, 2002; OECD, 2001). Uji toksisitas juga dapat memberikan gambaran kerusakan organ tubuh yang mungkin timbul akibat pengonsumsian bahan obat secara oral melalui pengamatan histopatologi (Ginting et al., 2016).

Hati sebagai organ metabolisme utama dan organ detoksifikasi menempati urutan pertama yang mendapat pengaruh toksik dari senyawa-senyawa yang masuk ke dalam tubuh, termasuk bahan obat (Ramadhan dan Tuljannah, 2011). Oleh karena itu, perlu dilakukan pengujian toksisitas untuk mengetahui kerusakan hati pada tikus karena diberi ekstrak daun $H$. capitata Jacq.

$$
\text { Bahan yang digunakan pada }
$$
penelitian ini adalah daun tumbuhan bakabaka ( $H$. capitata Jacq.), tikus putih ( $R$. norvegicus) jantan galur Wistar sebagai hewan uji, etanol $96 \%, 90 \%, 80 \%$ dan $70 \%$, kertas saring, kloroform, $\mathrm{NaCl}$ fisiologis, formalsaline, xylol, paraffin, albumin telur, pewarna Hematoxylin dan Eosin (HE), kapas, alumunium foil, aquades, entelan, handscound, serbuk gergaji, jagung.

Alat yang digunakan pada penelitian ini adalah timbangan, timbangan analitik, blender, oven, toples kaca yang dibungkus kain berwarna gelap, alat-alat gelas, rotary evaporator, sendok kayu, kaus tangan tebal, sonde lambung, silet, cetakan paraffin, gelas objek, gelas penutup, mikroskop, kandang, 
tempat makan dan minum tikus, kamera dan alat tulis

\section{PROSEDUR KERJA}

\section{Pembuatan Serbuk Simplisia}

Daun segar tumbuhan baka-baka $(H$. capitata Jacq.) seberat 6,1 kg dicuci bersih menggunakan air mengalir, kemudian disortasi basah untuk menghilangkan kotoran atau daun yang tidak layak untuk dijadikan sampel. Daun selanjutnya dirajang dan ditimbang. Sampel daun kemudian dikeringanginkan selama 2 minggu sampai kadar air tersisa $18 \%$, lalu disortasi kembali dan diblender sampai menjadi serbuk. Selanjutnya simplisia dikeringkan dalam oven dengan suhu $40^{\circ} \mathrm{C}$ selama 5 jam untuk mengurangi kadar air sampai sampai $5 \%$. Serbuk simplisia kemudian ditimbang lagi untuk mengetahui berat keringnya. Berat kering yang tersisa setalah proses oven selama 5 jam adalah $304 \mathrm{~g}$.

\section{Proses Ekstraksi}

Serbuk simplisia diekstraksi dengan metode maserasi mengacu pada Sharon (2013) dengan modifikasi. Serbuk simplisia baka-baka ( $H$. capitata Jacq.) sebanyak $304 \mathrm{~g}$ diekstraksi berulang menggunakan etanol 96\% selama masing-masing $3 \times 24$ jam dengan pengadukan. Maserat disaring lalu dipisahkan dari pelarut menggunakan rotary evaporator pada suhu $60^{\circ} \mathrm{C}$, lalu diuapkan hingga menjadi ekstrak kental (pasta). Ekstrak ditimbang dengan neraca analitik untuk mengetahui berat akhir ekstrak sampel daun baka-baka ( $H$. capitata Jacq.). Berat ekstrak kental yang dihasilkan dari $304 \mathrm{~g}$ berat kering sampel daun adalah sebesar $25 \mathrm{~g}$ berat pasta hasil pemisahan ekstrak menggunakan rotary evaporator.

\section{Pembuatan Dosis Ekstrak Daun Baka-}

\section{baka (Hyptis capitata Jacq.)}

Banyaknya ekstrak tiap perlakuan dihitung dengan mengalikan berat rata-rata (kg) tiap kelompok hewan uji dengan dosis ekstrak.

Penentuan dosis ekstrak $H$. capitata Jacq. yang diberikan mengacu pada $\mathrm{Xu}$ et al. (2013), bahwa ekstrak kasar daun $H$. capitata Jacq. memiliki nilai $\mathrm{LC}_{50}<1000$ $\mu \mathrm{g} / \mathrm{ml}$. Berdasarkan hal tersebut, penelitian ini menggunakan 3 dosis ekstrak yaitu 300 , 600, dan $900 \mu \mathrm{g} / \mathrm{kg}$ berat badan. Banyaknya ekstrak yang diberikan kepada hewan uji dihitung dengan cara mengalikan berat ratarata $(\mathrm{kg})$ tiap kelompok hewan uji dengan dosis ekstrak.

\section{Penyiapan Hewan Uji}

Hewan uji yang digunakan adalah 25 ekor tikus putih (Rattus norvegicus) jantan galur Wistar sehat, usia 8-10 minggu dengan berat badan 200-250g sesuai dengan standar yang telah diatur dalam OECD (2001). Tikus dibagi ke dalam 5 kelompok lalu diaklimatisasi dalam kandang selama 1 minggu dengan tetap diberikan makan dan minum ad libitum, kemudian dipuasakan selama 12 jam sebelum perlakuan dengan tetap diberikan minum.

\section{Perlakuan Hewan Uji}

Hewan uji yang telah dibagi ke dalam 5 kelompok, dengan masing-masing terdiri dari 5 ekor tikus putih ( $R$. norvegicus) sebagai ulangan, kemudian menerima perlakuan sebagai berikut: 
- $\mathrm{K}+$ : Kontrol positif (tanpa perlakuan)

- K- : Kontrol negatif (diberikan 0,5 ml etanol 96\%/hari)

- P1 : Diberikan ekstrak etanol daun baka-baka (H. capitata Jacq.) 300 $\mu \mathrm{g} / \mathrm{kg} \mathrm{bb} / \mathrm{ml} /$ hari secara oral

- P2 : Diberikan ekstrak etanol daun baka-baka (H. capitata Jacq.) 600 $\mu \mathrm{g} / \mathrm{kg} \mathrm{bb} / \mathrm{ml} /$ hari secara oral

- P3 : Diberikan ekstrak etanol daun baka-baka ( $H$. capitata Jacq.) 900 $\mu \mathrm{g} / \mathrm{kg} \mathrm{bb} / \mathrm{ml} /$ hari secara oral

Perlakuan diberikan selama 14 hari secara berturut-turut dengan pemberian ekstrak 1 kali dalam sehari dengan durasi 24 jam. Selama perlakuan tikus tetap diberikan makan dan minum ad libitum. Setelah hari ke-14 tikus dipuasakan selama 12 jam. Pada hari ke-15, tikus dianastesi dengan kloroform lalu dibedah untuk pengambilan organ hati. Kondisi morfologis hati diamati secara makroskopik dan didokumentasikan setelah sebelumnya dicuci dengan $\mathrm{NaCl}$ fisiologis. Seluruh prosedur perlakuan hewan coba berdasarkan pada standar OECD (2001).

\section{Pengamatan Makroskopik}

Hasil pengamatan secara makroskopik meliputi pengamatan morfologi dan warna sampel hati tikus putih ( $R$. norvegicus) yang diamati secara langsung dan menggunakan bantuan kamera untuk dilakukan dokumentasi penampakan hati secara makroskopik. Kriteria pengamatan secara makroskopik dideskripsikan berdasarkan penampakan struktur permukaan hati tikus putih ( $R$. norvegicus). Kategori hati normal dapat dilihat dengan permukaan hati yang rata dan halus serta warna yang terlihat merah kecoklatan. Kategori hati yang tidak normal dapat dilihat dengan permukaan hati yang kasar dan tampak bercak-bercak pada permukaan hatinya serta warna hati yang terlihat merah kehitaman (Tatukude dkk, 2014; Amalina, 2009).

\section{Pembuatan Preparat Histopatologi}

Preparat histopatologi dibuat menggunakan metode Kiernan yang mengacu pada Swarayana dkk (2012). Pembuatan preparat dimulai dengan fiksasi jaringan, dimana organ hati diambil bagian tengahnya dan dipotong kecil kemudian dicuci dengan $\mathrm{NaCl}$ fisiologis untuk membersihkan organ dari darah yang menempel. Sampel hati selanjutnya direndam dalam formalsalin selama 24 jam yang berfungsi untuk mengawetkan jaringan. Proses selanjutnya adalah dehidrasi yang bertujuan untuk menarik molekul air dari dalam jaringan dengan menggunakan seri alkohol bertingkat $(70 \%$, $80 \%$, 90\% dan 96\%). Jaringan yang telah dipotong kemudian dimasukan ke dalam xylol I dan II masing-masing 10 menit untuk proses penjernihan. Jaringan kemudian dimasukkan ke dalam paraffin cair dengan suhu $56^{\circ} \mathrm{C}$ selama 2 jam sebanyak 2 kali berturut-turut. Jaringan kemudian diambil menggunakan pinset dan dilakukan pemblokan menggunakan parafin blok sampai dingin dan membeku. Pemotongan (cutting) selanjutnya dilakukan menggunakan mikrotom dengan ketebalan $10 \mu \mathrm{m}$. Jaringan yang terpotong diletakan di atas air dalam waterbath untuk dikembangkan, kemudian ditangkap dengan gelas objek. Jaringan selanjutkan 
dikeringkan menggunakan hot plate.

Preparat siap diwarnai dengan Hematoxylin Eosin (HE).

Tahapan pewarnaan HE dengan metode Harris sebagai berikut: preparat di atas gelas objek direndam dalam xylol I, II masing-masing 15 menit untuk menghilangkan paraffin yang mungkin masih melekat di dalam jaringan. Preparat selanjutnya direndam dalam seri alkohol menurun 96\%, 90\%, 80\%, 70\% dan aquades sebanyak $1 \mathrm{kali}$, dengan waktu masing-masing 5 menit dan direndam dalam Hematoxylin selama 15 menit dan Eosin selama masing-masing 15 detik. Preparat kemudian diletakan ke dalam aquades selama kurang lebih 5 menit. Preparat selanjutnya direndam kembali ke dalam seri alkohol bertingkat $70 \%, 80 \%$, 90\% dan 96\% masing-masing 5 menit. Preparat setelah itu direndam lagi ke dalam xylol III dengan waktu 5 menit. Preparat kemudian dikeringkan dan dilakukan mounting dengan menggunakan entelan. Preparat siap untuk diamati di bawah mikroskop.

\section{Pengamatan Sampel Preparat}

Pengamatan preparat secara mikroskopik dilakukan dengan mengamati sampel hati tikus putih ( $R$. norvegivus) yang telah dibuat menjadi preparat, dengan memperhatikan kondisi jaringan hati tikus putih ( $R$. norvegicus) pada 5 bidang pandang. Parameter yang diamati meliputi jumlah sel yang normal, sel yang mengalami degenerasi parenkimatosa, degenerasi hidrofik dan nekrosis (Adikara dkk, 2013).
Pemeriksaan mikroskopik terhadap jaringan hati dari setiap kelompok percobaan diamati pada 5 lapang bidang pandang preparat, dengan masing masing bidang pandang dipusatkan pada 1 vena sentral yang terdapat pada masing-masing preparat yang akan diamati. Setiap vena sentral dibagi lagi menjadi 4 sudut bidang pandang dengan masing-masing sudut diwakili dengan mengamati 25 sel, sehingga dari ke 4 sudut pandang tadi dijumlahkan menjadi 100 sel untuk masing-masing 1 vena sentral yang diamati.

Masing-masing bidang pandang diamati menggunakan mikroskop dengan perbesaran 400x, kemudian setiap preparat dihitung nilai rata-rata degenerasinya dengan cara jumlah sel dikalikan dengan kategori nilai (1-4), sesuai dengan jenis degenerasinya. Sasaran yang dibaca adalah perubahan struktur histopatologis hepar tikus putih ( $R$. norvegicus). Kriteria penilaian disajikan pada Tabel 1, yang mengacu pada Maretnowati dkk (2005).

Tabel 1. Kriteria Penilaian Terhadap sel yang berdegenerasi

\begin{tabular}{lc}
\hline \multicolumn{1}{c}{ Jenis degenerasi } & Nilai/Skor \\
\hline Sel Normal & 1 \\
Degenerasi parenkimatosa & 2 \\
Degenarasi Hidropik & 3 \\
Nekrosis (sel piknotik, & 4 \\
karioreksis, kariolisis) & \\
\hline
\end{tabular}

Nilai skor akhir diketahui dengan cara mengalikan jenis degenerasi dengan nilai skor. Skor $=$ jumlah sel $\mathrm{x}$ jumlah skor (Sel normal 1, Degenerasi parenkimatosa 2, Degenerasi hidropik 3, Nekrosis 4). 


\section{Analisis Statistik}

Analisis statistik yang digunakan mengacu pada Bhara (2009). Data dari hasil pengamatan secara mikroskopik (jumlah sel yang rusak dari 5 bidang pandang mikroskop) terhadap 5 kelompok perlakuan pada sampel yang diperoleh diolah menggunakan software SPSS versi 24.0. Data kemudian diuji normalitasnya dengan Shapiro-Wilk. Jika data diperoleh normal,

\section{HASIL}

Pengamatan yang telah dilakukan secara makroskopik memperlihatkan adanya perubahan pada struktur morfologis hati, yaitu perubahan warna dan tekstur pada kelompok perlakuan seperti pada Gambar 1.

Berdasarkan Gambar 1 terlihat adanya perbedaan tingkat warna permukaan organ hati tikus putih ( $R$. norvegicus) pada setiap perlakuan. Selain itu ditemukan adanya bercak putih seperti pori-pori besar di seluruh permukaan bagian atas organ hati pada perlakuan K-, P1, P2 dan P3. Deskripsi struktur morfologi hati hasil pengamatan makroskopik pada setiap perlakuan disajikan pada Tabel 2.

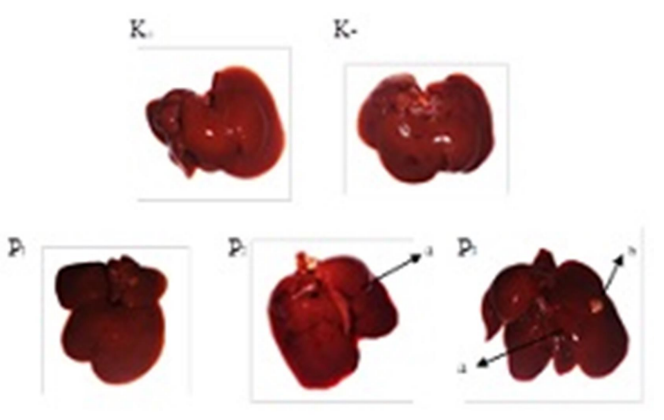

Gambar 1. Gambaran makroskopik hati tikus putih setelah 14 hari perlakuan: (a) maka selanjutnya dilakukan uji beda menggunakan statistik parametrik ANOVA. Jika hasilnya menunjukan perbedaan yang bermakna, maka dilanjutkan dengan uji DMRT. Jika hasil yang didapatkan adalah distribusi yang tidak normal, maka uji yang dilakukan menggunakan statistik non parametric Kruskal Wallis. Jika dari hasil uji statistik tersebut ada perbedaan yang bermakna, maka selanjutnya diuji dengan statistik Mann-Whitney.

bercak berwarna putih; (b) benjolan kuning

Pengamatan organ hati tikus putih $(R$. norvegicus) secara mikroskopik memperlihatkan gambaran kerapatan sel yang berbeda-beda pada setiap kelompok perlakuan. Pengamatan melalui mikroskop dengan perbesaran 400x memperlihatkan adanya gejala kerusakan pada perlakuan K-, P1, P2, dan P3, yaitu berkurangnya kerapatan sel hati, sinusoid yang semakin melebar, serta ditemukannya sel-sel yang rusak (Gambar 2).

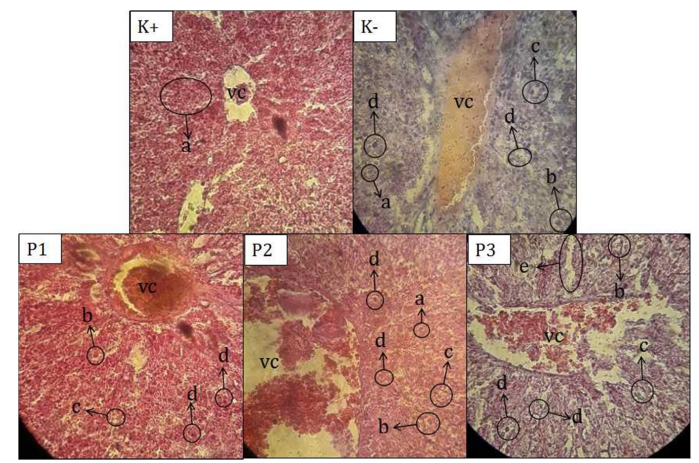

Gambar 2.Gambaran histopatologi hati tikus pada pengamatan mikroskopik setelah 14 hari perlakuan. (a) sel normal; (b) degenerasi 
parenkimatosa; (c) degenerasi hidropik; (d) nekrosis; (e) sinusoid lebar; (vc) vena sentralis; perbesaran 400x.

Data hasil perhitungan jumlah sel normal dan sel yang berdegenerasi pada 5 lapang pandang setiap perlakuan selanjutnya dikali dengan skor sesuai jenis degenerasi, kemudian dianalisis menggunakan ANOVA dan uji lanjut DMRT pada taraf signifikan 0,05 . Hasil analisis statistik tingkat kerusakan pada setiap kelompok perlakuan disajikan pada Tabel 3.

Tabel 2. Deskripsi struktur morfologi hati tikus pada pengamatan makroskopik setelah 14 hari perlakuan.

\begin{tabular}{ccc}
\hline Kelompok & Warna & Keterangan \\
\hline K+ & Merah kecokelatan & Tekstur \\
\hline K- & Merah kehitaman - merah keabu-abuan & Halus, terdapat bercak putih di permukaan atas \\
\hline P1 & Cokelat keabu-abuan - cokelat pucat & Halus, terdapat bercak putih di permukaan atas \\
\hline P2 & Merah kehitaman - merah keabu-abuan & $\begin{array}{c}\text { Halus, terdapat bercak putih di seluruh permukaan } \\
\text { atas, di beberapa lobus tampak bagian yang } \\
\text { menggelap dan agak keras jika disentuh }\end{array}$ \\
\hline P3 & Merah kehitaman - cokelat keabu-abuan & $\begin{array}{c}\text { Halus, terdapat bercak putih di permukaan atas, dan } \\
\text { terdapat benjolan kuning seperti lemak pada } \\
\text { permukaan hati }\end{array}$ \\
\hline
\end{tabular}

Tabel 2 menunjukkan adanya perbedaan penampakan organ hati pada setiap perlakuan yang mengindikasikan adanya kerusakan hati pada perlakuan K-, P1, P2, dan P3. Kerusakan hati ditandai dengan perubahan warna hati yang seharusnya merah kecokelatan menjadi cokelat pucat atau merah kehitaman, juga munculnya bercak-bercak putih dan atau adanya benjolan kuning seperti lemak di permukaan bagian atas hati tikus.

Tabel 3. Hasil analisis statistik tingkat kerusakan mikroskopik hati tikus

\begin{tabular}{|c|c|c|c|c|c|c|}
\hline \multirow{2}{*}{ Kelompok } & \multirow{2}{*}{$\begin{array}{c}\begin{array}{c}\text { Sel } \\
\text { Normal }\end{array} \\
\text { Skor }\end{array}$} & \multirow{2}{*}{$\begin{array}{c}\begin{array}{c}\text { Degenerasi } \\
\text { parenkimatosa }\end{array} \\
\text { Skor }\end{array}$} & \multirow{2}{*}{$\begin{array}{c}\begin{array}{c}\text { Degenerasi } \\
\text { Hidropik }\end{array} \\
\text { Skor }\end{array}$} & \multirow{2}{*}{$\begin{array}{c}\text { Nekrosis } \\
\text { Skor }\end{array}$} & \multicolumn{2}{|c|}{ Total } \\
\hline & & & & & Skor & Nilai \\
\hline $\mathrm{K}+$ & $\begin{array}{c}89,67 \pm 5 \\
51 \mathrm{c}\end{array}$ & $2,00 \pm 2,20 a b$ & $\begin{array}{c}20,00 \pm 10,54 \\
a b\end{array}$ & $\begin{array}{c}10,67 \pm 11 \\
55 a\end{array}$ & $\begin{array}{c}122,33 \pm 14,2 \\
9 a\end{array}$ & $\begin{array}{c}489,33 \pm 57 \\
18 a\end{array}$ \\
\hline K- & $46 \pm 2,00 a$ & $8 \pm 5,29 b$ & $102 \pm 22,62 d$ & $48 \pm 10,58 a$ & $204 \pm 14,73 c$ & $816 \pm 58,92 c$ \\
\hline P1 & $\begin{array}{c}81,8 \pm 11 \\
53 c\end{array}$ & $2 \pm 0,00 a b$ & $9,4 \pm 5,51 \mathrm{a}$ & $\begin{array}{c}47,2 \pm 29,4 \\
8 a\end{array}$ & $\begin{array}{c}140,4 \pm 19,55 \\
a b\end{array}$ & $\begin{array}{c}561,6 \pm 78,6 \\
1 \mathrm{ab}\end{array}$ \\
\hline P2 & $\begin{array}{c}66,6 \pm 7,5 \\
1 \mathrm{~b}\end{array}$ & $8,4 \pm 6,43 b$ & $49,6 \pm 19,66 c$ & $\begin{array}{c}43,2 \pm 14,0 \\
5 a\end{array}$ & $\begin{array}{c}167,8 \pm 24,03 \\
b\end{array}$ & $\begin{array}{c}671,2 \pm 96,1 \\
1 b\end{array}$ \\
\hline P3 & $\begin{array}{c}53,5 \pm 11 \\
62 a\end{array}$ & $0,00 \pm 0,00 a$ & $39 \pm 10,68 b c$ & $\begin{array}{c}134 \pm 55,18 \\
b\end{array}$ & $\begin{array}{c}226,5 \pm 36,82 \\
c\end{array}$ & $\begin{array}{c}906 \pm 147,28 \\
\text { C }\end{array}$ \\
\hline
\end{tabular}




\section{PEMBAHASAN / DISCUSSION}

Hasil penelitian secara makroskopik dan mikroskopik pada hati tikus memperlihatkan adanya kerusakan yang terjadi pada masing-masing perlakuan dosis ekstrak daun baka-baka ( $H$. capitata Jacq.), dimana semakin tinggi dosis yang diberikan maka semakin mempengaruhi tingkat kerusakan yang terjadi pada hati.

Pengamatan secara makroskopik (Gambar 1 dan Tabel 2) menunjukkan perbedaan baik penampakan warna maupun tekstur pada permukaan organ hati tikus putih ( $R$. norvegicus). Perlakuan $\mathrm{K}+$ (kontrol positif) sebagai pembanding memperlihatkan organ hati yang berwarna merah kecokelatan dengan tekstur permukaan hati yang halus, yang mana menunjukkan bahwa $\mathrm{K}+$ memiliki organ hati normal (tidak mengalami kerusakan) secara makroskopik. Berbeda dengan $\mathrm{K}+$, warna hati berubah menjadi cokelat keabu-abuan hingga cokelat pucat pada perlakuan P1 dan merah kehitaman hingga cokelat keabu-abuan pada perlakuan K- (kontrol negatif), P2, dan P3. Hati pada keempat perlakuan tersebut memiliki tekstur permukaan yang halus dan umumnya terdapat bercak putih di permukaan atas. Pada perlakuan P3 juga ditemukan benjolan kuning seperti lemak pada permukaan hati. Perubahan warna dan tekstur permukaan hati tikus mengindikasikan adanya kerusakan pada organ tersebut. Kerusakan pada K- disebabkan oleh toksik akibat pemberian etanol $96 \%$ setiap hari, sedangkan kerusakan pada P1-P3 disebabkan oleh toksik akibat pemberian ekstrak daun baka-baka (H. capitata Jacq.) dengan dosis bertingkat.

Hasil yang diperolah dari penelitian makroskopik ini serupa dengan kesimpulan yang dikemukakan oleh Cahyono dkk (2012) dan Utomo (2015) bahwa warna yang terlihat pucat sampai kehitaman menunjukan hati rusak/abnormal. Pendapat lain juga dikemukakan oleh Saefulhadjar et al (2008) apabila warna hati pucat menunjukkan bahwa kadar Fe pada hati rendah karena acupan Fe ke tubuh menjadi berkurang, yang diperkirakan akibat adanya pengikatan asam fitat pada saluran pencernaan. Simamora (2011) juga menyebutkan bahwa kelainan pada hati secara fisik biasanya ditandai dengan adanya perubahan warna. Bercak putih yang tampak pada makroskopik pada kelompok perlakuan P2 dan P3 serupa dengan pendapat Robins dan Kumar (1992), bahwa hati yang normal memiliki permukaan rata dan halus serta berwarna merah kecokelatan, sedangkan hati yang abnormal memiliki permukaan berbintikbintik dan mengalami perubahan warna.

Hasil pengamatan secara mikroskopik juga mendukung hasil pengamatan 
makroskopik. Berdasarkan Tabel 2, dapat dilihat bahwa pada semua perlakuan dapat ditemukan adanya sel-sel yang mengalami kerusakan, namun jumlah sel pada setiap jenis kerusakan (degenerasi parenkimatosa, degenerasi hidropik, dan nekrosis) tidak bergantung pada perlakuan yang diberikan. Sel yang mengalami degenerasi parenkimatosa ditandai dengan keadaan sel yang mengalami pembengkakan diikuti dengan pembengkakan inti selnya akibat deri cairan yang masuk kedalam sel, sedangkan degenerasi hidropik disebabkan oleh gangguan pada membran sel. Terlihat seperti vakuola-vakuola kecil atau besar akibat cairan yang memenuhi sitoplasma disebabkan sel yang sakit, sehingga terjadilah akumulasi cairan di dalam sel. Kerusakan sel terparah adalah nekrosis, yang ditandai dengan inti sel yang mati dapat terlihat lebih kecil, kromatin dan serabut retikuler menjadi berlipat-lipat. Inti sel juga menjadi lebih padat (piknotik) yang akhirnya hancur bersegmen-segmen (karioreksis), dan kemudian sel menjadi eosinofilik (kariolisis) yang pada akhirnya sel mengalami kematian (Gambar 2). Hal ini sejalan dengan pendapat yang dikemukakan oleh Suhita dkk (2013).

Hasil skoring dan uji statistik anova pada parameter sel yang dinilai (sel normal, degenerasi parenkimatosa, degenerasi hidropik, nekrosis, dan total nilai) memperlihatkan hasil yang berbeda. Hasil skoring pada sel normal menunjukkan bahwa tikus putih yang diberi perlakuan P3 memiliki sel normal yang lebih sedikit jika dibandingkan dengan P2 atau P1. Semakin besar konsentrasi ekstrak daun baka-baka (H. capitata Jacq.) yang diberikan maka semakin sedikit jumlah sel normal pada hati. Jumlah sel normal hati tikus pada perlakuan P3 tidak berbeda nyata dengan jumlah sel normal pada perlakuan K-. Sementara itu jumlah sel normal hati tikus pada perlakuan $\mathrm{P} 1$ tidak berbeda nyata dengan jumlah sel normal hati tikus pada perlakuan $\mathrm{K}+$.

Sel hati yang mengalami degenerasi parenkimatosa terendah justru terdapat pada tikus yang diberi perlakuan P3. Pada Tabel 2. terlihat bahwa pada perlakuan P3 sel-sel hati tidak ada yang mengalami degenerasi parenkimatosa. Sementara itu pada perlakuan P2 dan K- memiliki sejumlah sel yang mengalami degenerasi parenkimatosa meskipun kedua perlakuan tersebut tidak berbeda nyata. Perlakuan P1 dan dan K- tidak berbeda nyata terhadap jumlah sel hati yang mengalami degenerasi parenkimatosa.

Sel hati yang mengalami degenerasi hidropik tertinggi diperoleh pada tikus yang mendapatkan perlakuan K- kemudian diikuti oleh tikus yang mendapatkan perlakuan P2 dan P3 meskipun keduanya tidak berbeda nyata. Sementara itu pada tikus yang mendapatkan perlakuan P1 memiliki jumlah sel hati yang mengalami degenerasi 
hidropik terendah dan tidak memiliki perbedaan yang nyata dengan sel hati tikus yang mendapatkan perlakuan $\mathrm{K}+$.

Sel hati tikus yang mengalami nekrosis tertinggi diperoleh pada tikus yang mendapatkan perlakuan P3. Tidak ada beda nyata antara perlakuan $\mathrm{K}+, \mathrm{K}-, \mathrm{P} 1$ dan P2 terhadap jumlah sel hati tikus yang mengalami nekrosis.

Secara keseluruhan, nilai kerusakan sel hati tertinggi diperoleh pada tikus yang mendapatkan perlakuan P3 dan K- dan kedua perlakuan tersebut (P3 dan K-) tidak berbeda nyata terhadap jumlah sel hati yang mengalami kerusakan. Tidak ada perbedaan yang nyata antara perlakuan $\mathrm{P} 1$ dan P2 terhadap nilai kerusakan sel hati. Nilai kerusakan sel hati terendah diperoleh pada tikus yang mendapatkan perlakuan $\mathrm{K}+$.

\section{DAFTAR PUSTAKA}

Adikara, I. P. A., Ida B. O. W., dan I Wayan, S. 2013. Studi Histopatologi Hati Tikus Putih (Rattus Norvegicus) Yang Diberi Ekstrak Etanol Daun Kedondong (Spondias Dulcis G.Forst) Secara Oral. Buletin Veteriner Udayana, ISSN: 5(2), 2085-2495.

Almtorp, G. T., Hazell, A. C., and Torssell, K. B. G. 1991. A lignin and pyrone and other constituents from Hyptis capitata. Phytochemistry, 30(8), 27532756.

Alvionita. 2017. Studi Etnobotani Tumbuhan Obat Masyarakat Suku Topo Uma di Desa Berdikari Kabupaten Sigi
Pengamatan makroskopik dan mikroskopik pada organ hati tikus putih ( $R$. norvegicus) yang diberikan ekstrak daun tumbuhan baka-baka ( $H$. capitata Jacq.) menunjukan adanya gejala kerusakan dengan berbagai tingkatan. Pengamatan secara maksroskopik memperlihatkan semakin tinggi dosis yang diberikan pada setiap kelompok perlakuan maka akan semakin mempengaruhi tingkat kerusakan organ hati, yang dapat dilihat dari tingkatan perubahan warna dan tekstur yang terlihat pada permukaan organ hati tikus putih $(R$. norvegicus). Pengamatan secara mikroskopik juga memperlihatkan jika semakin tinggi dosis yang diberikan maka akan semakin mempengaruhi tingkat kerusakan sel dari organ hati tikus putih $(R$. norvegicus).

Sulawesi Tengah. Skripsi. Universitas Tadulako. Palu.

Amalina, N. 2009. Uji Toksisitas Akut Ekstrak Valerian (Valeriana Officinalis) Terhadap Hepar Mencit Balb/C. Skripsi. Fakultas Kedokteran Universitas Diponegoro. Semarang.

Bhara, M. L. A. 2009. Pengaruh Pemberian Kopi Dosis Bertingkat Per Oral 30 Hari Terhadap Gambaran Histologi Hepar Tikus Wistar. Skripsi. Fakultas Kedokteran Universitas Diponegoro. Semarang.

Cahyono, E. D., Atmomarsono, U. dan Suprijatna, E. 2012. Pengaruh Penggunaan Tepung Jahe (Zingiber 
Offinale) Dalam Ransum Terhadap Saluran Pencernaan Dan Hati Pada Ayam Kampung Umur 12 Minggu. Animal Agricultural Journal, 1(1), 6574.

Ginting, H., Dalimunthe, A., and Reveny, J. 2016. Acute Toxicity Effect of The Ethanolic Extract of Watercress Herb (Nasturtium officinale R. Br.) in Mice. Indonesian Journal of Cancer Chemoprevention, 7(1), 9-16.

Manggung, R. E. R. 2008. Pengujian toksisitas akut Lethal Dose 50 (LD50) ekstrak etanol buah belimbing wuluh (Averrhoa bilimbi L.) pada mencit (Mus musculus albinus). Skripsi. Fakultas Kedokteran Hewan, Institut Pertanian Bogor. Bogor.

Maretnowati N., Widyawaruyanti A., Santosa M. H. 2005. Uji toksisitas akut dan subakut ekstrak etanol dan ekstrak air kulit batang Artocarpus champeden spreng dengan parameter histopatologi hati mencit. Majalah Farmasi Airlangga. 5(3). 91-5.

OECD. 2001. Acute Oral Toxicity-Acute Toxic Class Method. OECD Guidelines for Testing Chemicals, 423(1), 1-14.

Ramadhan, A., dan Tuljannah, M. 2011. Aktivitas Hepatoprotektor Ekstrak Meniran Hijau (Phyllanthus niruri L.) Terhadap Tikus Putih (Rattus norvegicus) yang Diinduksi dengan Karbon Tetraklorida $\left(\mathrm{CCl}_{4}\right)$. Eukariotik, 9(2), 26-30.

Robbins, S. L., dan Kumar, V. 1992. Buku Ajar Patologi 1. Surabaya: Kedokteran EGC.

Saefulhadjar, D. I., Hemawan, dan Kamil, K. A. 2008. Penyerapan kadmium pada ayam kampung yang di beri dedak padi dalam ransum. Jurnal Media Peternakan. Fakultas Peternakan Universitas Padjajaran. 31(2), 122127.

Sharon, N., Anam, S., dan Yuliet. 2013. Formulasi Krim Antioksidan Ekstrak Etanol Bawang Hutan (Eleutherine palmifolia L. Merr). Online Jurnal of Natural Science, 2(3), 111-122.

Simamora, N. 2001. Performans produksi dan karakteristik organ dalam ayam kampung umur 12-16 minggu yang di infeksi cacing Ascaridia galli dan disuplementasi ekstrak daun jarak pagar (Jatropha curcas Linn). Skripsi. Fakultas Peternakan, Institut Pertanian Bogor. Bogor.

Soemardji, A. A., Kumolosasi, E., dan Aisyah, C. 2002. Toksisitas akut dan penentuan DL50 oral ekstrak air daun gandarusa (Justicia gendarussa Burm. F.) pada mencit Swiss Webster. Jurnal Matematika dan Sains, 7(2), 57-62.

Suhita, N. L. P. R., Sudira, I. W., dan Winaya, B. O. 2013. Histopatologi ginjal tikus putih akibat pemberian ekstrak pegagan (Centella asiatica) peroral. Buletin Veteriner Udayana, 5(2), 71-78.

Swarayana, M. I., Sudira, W., dan Berata, K. 2012. Perubahan Histopatologi Hati Mencit (Mus musculus) yang Diberikan Ekstrak Daun Ashitaba (Angelica keiskei), 4.(2), 119-125.

Tatukude, R. L., Loho, L., Lintong, M. P. 2014. Gambaran Histopatologi Hati Tikus Wistar Yang Diberikan Boraks. Jurnal e-Biomedik (eBM), 2(3), 62096215.

Utomo, B. 2015. Pengaruh Pemberian Gelatin Tulang Ayam Terhadap 
Gambaran Makroskopis Dan Mikroskopis Hati Dan Ginjal Mencit (Mus musculus). Skripsi. Fakultas Peternakan, Universitas Hasanuddin Makassar. Makassar.
Xu, D. H., , Huang, Y. S., Jiang, D. Q., and Yuan, K. 2013. The essential oils chemical compositions and antimicrobial, antioxidant activities and toxicity of three Hyptis species. Pharmaceutical Biology, 51(9), 11251130. 